\title{
CASH FLOW FORECASTING FOR INTERNATIONAL PROJECTS IN THE PROCESS OF CAPITAL BUDGETING DURING THE COVID-19 PANDEMIC
}

\author{
Biljana Pejović ${ }^{1}$ \\ Dragana Trifunović ${ }^{2}$ \\ Aleksandra Živaljević ${ }^{3}$
}

DOI: https://doi.org/10.31410/ITEMA.2020.129

\begin{abstract}
By predicting cash flows in the capital budgeting procedure, the profitability of an investment at the international level is determined in advance. Although investing globally provides greater opportunities for earnings, cost reduction and business diversification, all risks posed by international business must be considered when choosing a discount rate. In addition to the risks inherent in cross-border business such as exchange rate risk, country risk, the risks caused by the pandemic crisis, which relate primarily to measures taken by states to protect the population by introducing quarantine, restricting the flow of people, goods and capital, as well as activities that are endangered by a pandemic, must be considered too. If all the risks that determine the discount rate are well assessed, the cash flow forecast will be more accurate.
\end{abstract}

Keywords: Cash flows, Capital budgeting, Discount rate, Pandemic.

\section{INTRODUCTION}

$\mathrm{G}$ lobalization as a process of great economic changes (Glushkova, Lomakina, Sakulyeva, 2019, pp. 876-884), that are reflected in the social, political and cultural aspect of overall life has been greatly stimulated by the emergence and development of international corporations. High concentration of capital and business in several countries are their main characteristic. The development of technology and the removal of barriers to the free flow of products, services, people and capital have contributed to the fact that two thirds of the world capital market are in their possession.

Cross-border business has brought greater opportunities for more cost-effective business but also greater challenges in the management process. Some of the advantages of cross-border business are: obtaining and using cheaper resources, conquering new markets, establishing cost centers in countries with high tax rates, and profit centers in countries with low tax rates, in order to optimize the tax burden. The existence of the possibility of production diversification and the relocation of production capacities to countries with more favorable conditions, cheaper resources are other advantages of their business. Investing in other countries increases sales outside the country of establishment, increases market shares and makes extra profit. International diversification additionally affects the reduction of corporate exposure to the economic conditions of the country in which they were initially established, but it also

Faculty of Social Sciences, Bulevar umetnosti $2^{\mathrm{a}}$, Belgrade, Serbia

Faculty of Social Sciences, Bulevar umetnosti $2^{a}$, Belgrade, Serbia

Higher Colleges of Technology, Abu Dhabi, United Arab Emirates 
additionally affects the exposure of corporations to business risks imposed by the international environment.

The earning capacity of corporations is determined by a good assessment of investment opportunities at the global level (Putra, 2019, p.818-826). Decisions about the return of investment must be consistent in order to maximize the value of the shares. Capital budgeting or evaluation of economic efficiency of investments includes the process of identification, analysis and selection of investment projects whose returns are expected to last longer than a year. It includes the development of investment project proposals that are consistent with the goals of corporations, the assessment of cash flows for each project individually, the selection of projects based on value maximization as eligibility criteria.

The pandemic crisis caused by the Covid-19 virus also pointed to some negative effects of international investment (Adegboye, Adekunle, Eisen, McBryde, Pak, Rahman, 2020.). The health threat to the population has caused the re-establishment of borders and the introduction of limits by states that can cause a slowdown and significantly higher costs of project implementation. If the implementation of previously contracted projects cannot be postponed due to the current situation, it is necessary to apply a discount rate when projecting cash flows, which represents all additional risks caused by the pandemic. Although it is still too early to draw conclusions because the pandemic is still going on, many countries will enter a period of recession and falling GDP and there will be a large increase in the number of unemployed.

\section{CAPITAL BUDGETING}

Capital budgeting is used to assess the profitability of investments, as a technique that can indicate in advance to investors the extent to which the selected investment is profitable (Justice, Pious, Yeboah, 2020, p. 33). The four alternative methods used to evaluate and select investment projects in practice are the following: net present value, internal rate of return, payback period, and profitability index. Discounted cash flow methods provide the best measure of the real returns of projects because they are based on future cash flows and consider the time value of money.

These methods pay special attention to accounting reports (balance sheet, income statement and cash flow statement) from the past, because they are used to project future cash flows, and have proven to be one of the best valuation methods in market economies. The most commonly used method of capital budgeting involves calculating the net present value, which is determined by discounting the projected cash flows that will be generated by a particular investment. The net present value is a monetary measure of return, and the internal rate of return is a percentage measure of return of investment.

The inputs necessary for capital budgeting are: initial investment, demand forecast, price at which products will be placed on the market, fixed and variable costs, payback period, residual value and expected rate of return (Messer, 2020, p. 302). All parameters are highly dependent on exchange rate fluctuations, the tax legislation of the country in which it is invested, as well as the ban on transfers between the parent company and the branch, if any.

International capital budgeting is an identical procedure that requires a more complex analysis. Internationally, there are many more factors that affect the level of the discount rate, which includes all risk exposures. The process of estimating the direct costs of a project begins with 
a reference to experience, if similar projects have been carried out in the past, by market research or by scenario analysis.

The Net Present Value (NPV) method involves discounting of future cash flows back to present value (Blaset Kastro, Kulakov, 2020.) Based on this criterion, those projects whose net present value is higher than zero are eligible. The present value of the initial investment is the sum of discounted net inflows, because the investment is made at the beginning of the period. The Net Present Value is the amount by which the present value of the cash inflows exceeds the present value of the cash outflows. A positive Net Present Value means that the rate of return of capital investment is greater than the discount rate used in the analysis.

The internal rate of return is represented as a metric used in financial analysis to estimate the profitability of potential investments. The internal rate of return is a discount rate that makes the net present value (NPV) of all cash flows equal to zero in a discount cash flow analysis. The internal rate of return for an investment project is the discount rate that equates the present value of expected cash flows with the initial expenditure. If the internal rate of return is higher than the required rate of return the project is eligible, otherwise the project is rejected. When deciding between projects with the same degree of risk, a project with a higher internal rate of return is a better investment.

Payback Period represents the amount of time required for the cash flows generated by the investment to repay the cost of the original investment. The number of years required to recoup the investment is the payback period. The payback period is the period required for the cumulative cash flows from the invested project to equal the initial cash outflow. If the calculated return period is less than the maximum acceptable, the project is accepted, and if not, then it is rejected.

The discount rate is an integral part of the analysis and it must reflect the risk level of the capital investment. The discount rate can represent several different approaches for the company. It may represent the cost of capital such as the cost of borrowing money to finance the capital expenditure or the cost of using the company's internal funds, or it may represent the rate of return needed to attract outside investment for the capital project. It must cover all risks that may affect the implementation of the project. Choosing the proper discount rate is important for an accurate Net Present Value analysis.

Another measure to determine the acceptability of a capital investment is the Profitability Index (PI). The Profitability Index is computed by dividing the present value of cash inflows of the capital investment by the present value of cash outflows of the capital investment. If the Profitability Index is greater than one, the capital investment is accepted. If it is less than one, the capital investment is rejected.

\section{CASH FLOW FORECASTING}

Discounted cash flow methods provide the best measure of the real returns of projects because they are based on cash flows and consider the time value of money. For good estimates, it is necessary to consider all the risks that determine the discount rate.

Determining the value that will be generated from an investment includes predicting cash flows and the period expected to return the initial investment, determining the internal rate of return, discounting the projected cash flows, adding the present values to determine the profitability 
of the initial investment. At the beginning, the construction of financing is determined and the weighted average cost of capital is determined.

The most important factors influencing the choice of discount rate are the financial condition of the company in which it is invested, the financial mix, in terms of the price of borrowed resources and the price of own sources, the economic situation, trends in the industry in which the company operates, supply and demand ratio and country risk. If starting from cash flow after debt servicing, the discount rate will be based on the opportunity price of capital, while discounting the cash flow before servicing debts will use a discount rate based on the weighted average cost of capital. Choosing the appropriate discount rate requires to consider all revenues and expenses in accordance with market prices. Cash flow before servicing debts is used by investors in purchase or takeover transactions, because the cash flow defined in this way provides an insight into credit capacity and considers all the possibilities of financing transactions from a new loan. Cash flow after debt service is important for creditors, management and shareholders, given that the cash flow defined in this way takes into account financial needs (Putri, 2020, p. 79).

Discount rates may vary over time. The first reason is that the level of interest rates on borrowed funds can change over time. This usually happens if the interest rate is linked to one of the reference rates whose movement is conditioned by the supply and demand for financial resources. Another reason is that risk characteristics can be expected to change over time. The third reason is that the financial mix of a project can change over time, resulting in changes in the cost of equity and borrowed capital.

If invest in countries that have high inflation rates, it is difficult to reliably determine the amount of net present value. Although inflation affects both costs and revenues in the same direction (causes them to rise), the end result may be different. This is especially pronounced in projects involving the import of components and the sale of finished products in the local market. In that case, inflation has a greater impact on revenues than on project costs.

There are a number of reasons that affect the emergence of risk, including the project itself. Risk is also affected by competition, industry trends, international developments, macroeconomic factors and prices of resources in the global market. However, it is not necessary to perform an analysis of all types of risks when estimating the discount rate. Initially, differentiation of risk sources is performed at the project level. Among the various sources of risk that are analyzed during capital budgeting, only those risks that cannot be diversified should be considered. This type of risk varies from company to company depending on whether it is a company whose shares are publicly traded or not. After identifying the risk at the company level, the risk at the project level is determined and measured. If companies invest in homogeneous projects, with similar risk profiles, the cost of the company's share capital is used. If the company is diversified and engaged in different activities, and projects within each activity have a similar risk, the cost of share capital is also used for that activity. If the project is unique in terms of risk, the cost of share capital that is specific to that project is calculated and used. After assessing the risk of share capital and the risk of default on the company's debt, there are two ways to include the risk in the analysis. One way is to calculate the cost of share capital and debt that will reflect the risk of the project. Riskier projects will have higher costs. Another way is to adjust cash flows using a risk-reflecting discount rate.

The combined effect of inflation and exchange rate fluctuations on net cash flow may act neutrally from the parent company's perspective. The exchange rate of countries with high 
inflation weakens over time. Although the branch's earnings are expressed in local currency due to the impact of inflation, when converted into the parent company's currency, the effect of growth is lost (the currency of the country in which the branch is weak in relation to the parent company's currency). This effect of exchange rate neutralization and inflation rarely occurs in practice because inflation is only one of the factors influencing the exchange rate, and in addition there is no guarantee that the local currency will depreciate when the inflation rate is relatively high.

Since the introduction of the pandemic caused by the Covid-19 virus, business conditions in the international arena have changed. The behavior of the virus is atypical, in terms of the duration of the infection, the way it is transmitted, the behavior of the virus at high summer temperatures, so that many predictions of even the most eminent experts were wrong. A large number of people have become infected and a state of emergency has been declared in many countries. Regardless of the measures taken by the states in order to protect the spread of the infection, the mortality rate in almost all countries is extremely high.

According to data released by the World Health Organization on September 19, 2020, there have been 30,369,778 confirmed cases of COVID -19, including 948,795 deaths (World Health Organization, 2020.). Some countries have introduced a state of quarantine and bans on the movement of the population, not only within state borders, but also within cities, as is the case in Italy. Some had a much more liberal stance, such as Sweden. The final conclusion on how to behave in a pandemic will be made when the pandemic is stopped or at least brought under control. Acquiring global immunity through vaccination of the population is still not feasible, because until practical application, vaccines must pass a phase of testing that requires time.

Many companies, whether privately or state-owned, have had to provide conditions for their employees, which would protect them against infection. Companies had a better organization of their business, which could enable employees to do their jobs online, if it was feasible, from home. It turned out that high-tech activities were in the lead.

An additional problem is the increase in the unemployment rate. All over the world, employers have laid off surplus labor, both due to the reduction in the volume of business and the inability to provide the conditions prescribed by state regulations for the protection of employees in the workplace. All over the world, many employees are expected to lose their jobs. Cash flow forecasting costs will be further increased by employee health care requirements during a pandemic. It is still too early to consider these figures, but it should be borne in mind that these developments will affect the cost of labor used in forecasting cash flow costs.

Why is this information important for international projects? The discount rate used in the process of calculating the net present value should include all risks that may directly or indirectly affect the implementation of projects and affect the formation of the price of input and outputs. Higher risk requires a higher discount rate which affects the reduction of the net present value and profitability of the project. The state of panic and fear affects the human psyche in terms of savings, reduced consumption and limited movement.

The pandemic did not affect all industrial areas equally. The biggest changes in business have occurred in the field of tourism, transport, hotel services, catering, real estates' rental, organization of events that involve numerous gatherings of people, such as sports events, concerts, etc. In some industries they have found a transitional solution. Traders and restaurant 
owners delivered the ordered products online to the home address, in order to maintain good traffic as much as possible.

If it is impossible to delay all investments in these industries, a discount rate should be carefully formed and it would include all the risks already mentioned.

Based on research conducted to create the most effective policies to overcome the harmful effects of Covid-19 on the economy and the wider community in March 2020, based on the views of representatives of companies, local governments and civil society organizations, the biggest challenges they face are problems with collection and liquidity (for as many as $63 \%$ of respondents), drop in demand (45\%), but also problems with regular payment of wages to workers $(32 \%)$, organization of work $(29 \%)$ and the possibility of regular settlement of obligations to the state (Nacionalna alijansa za lokalni ekonomski razvoj, 2020, p.4)

According to data published by the World Health Organization, the number of deaths in the world is constantly increasing. The number of deaths in the world due to the Covid-19 virus pandemic, on September 19, 2020: Americas 15,333,470, South-East Asia 5,973,186, Europe 5,149,121, Eastern Mediterranean 2,199,096, Africa 1,141,044 and Western Pacific 573,120 (World Health Organization, 2020.). It is expected that the measures introduced by countries to protect the population will be even more rigorous, which should affect the discount rate in the future.

\section{CONCLUSION}

The realization of international projects during the pandemic caused by the Covid-19 virus poses new challenges for investors. Determining whether and to what extent projects are profitable can be correctly calculated only if a discount rate is applied when forecasting future cash flows, which, in addition to all the risks caused by international business, also include all additional risks brought by the pandemic. Investments in the field of tourism, transport, hotel services, catering, organization of events that include numerous gatherings of people, such as sports events, concerts require higher discount rates. All projects that require the gathering of a larger number of people, their movement during the pandemic are additionally risky. Until the pandemic is over, or at least not brought under control, due to the health protection of the population, investment in these industrial areas should be postponed or in the calculation of their profitability one should be realistic. When choosing the discount rate used to estimate future cash flows, the most important thing is to include all the risks that may affect the implementation of the project.

\section{REFERENCES}

Blaset, Kastro, A., N., Kulakov, N., Y., (2020). Risk-adjusted discount rates and the present value of risky non-conventional projects, The Engineering Economist. https://doi.org/10.1080/0013791X.2020.1815918

Glushkova, S., Lomakina, O., Sakulyeva, T., (2019). The Economy of Developing Countries in the Context of Globalization: Global Supply Chain Management, International Journal of Supply Chain Management, 8(1), 876-884.

Justice, A., Pious, O., Yeboah, E., N., (2020). Capital Budgeting as a Tool of Management Decision Making: A Case Study of National Investment Bank Limited, Research Journal of Finance and Accounting, 11(4), 33-41. 
Messer, R. (2020). "Making a Lot of Decisions", Financial Modeling for Decision Making: Using MS-Excel in Accounting and Finance. Emerald Publishing Limited. https://doi.org/10.1108/978-1-78973-413-320201018

Nacionalna alijansa za lokalni ekonomski razvoj (2020). Covid-19, Uticaj na privredu i lokalne zajednice; Percepcija predstavnika privatnog, javnog i civilnog sektora

Adegboye, O. A., Adekunle, A. I., Eisen, D. P., McBryde, E. S., Pak, A., Rahman, K. M., (2020). Economic Consequences of the COVID-19 Outbreak: the Need for Epidemic Preparedness, Front Public Health, 8(241). https://doi.org/10.3389/fpubh.2020.00241

Putra, Y. M., (2019). Analysis of Factors Affecting the Interests of SMEs Using Accounting Applications. Journal of Economics and Business, 2(3), 818-826. https://doi.org/10.31014/aior.1992.02.03.129

Putri, R., S., T., (2020). The Effect of Return on Assets, Free Cash Flow, and Debt to Equity Ratio on Company Value, EPRA International Journal of Multidisciplinary Research (IJMR), 6(10), 76-84. https://doi.org/10.36713/epra5329

World Health Organization (2020) WHO Coronavirus Disease (COVID-19) Dashboard, https://covid19.who.int/, Accessed on: 2020/09/19 